\title{
The prevalence of temporomandibular dysfunction in patients with spine pain
}

\author{
A prevalência de disfunção temporomandibular em portadores de dor na \\ coluna vertebral.
}

Diogo Suriani Ribeiro', Brayner Gomes e Silva', Nayara da Silva Oliveira', Amanda Oliveira Almeida', Maikon Gleibyson Rodrigues dos Santos², Luiz Guilherme Cardoso da Silva², Thiago Vilela Lemos',2

\begin{abstract}
Introduction: The Temporomandibular disfunction (TMD) is a composite of signs and symptoms manifested as a consequence of disorders in the stomatognathic system. Temporomandibular Joint Disorders can cause problems in the cervical and lumbar spine and vice versa. Objective: To identify the prevalence of TMD in people with pain in the spine. Method: It is an analytical quantitative transversal study. Study participants were 60 volunteers of both sexes, from four orthopedic physical therapy clinics, with patients being treated for painful conditions vertebral in Goiânia - GO. Questionnaire Anamnesic Fonseca (1994) was used to capture and interpret data as well as verification of temporomandibular dysfunction to characterize the severity of TMD symptoms. The software used for statistical analysis was the BioEstat 5.0. Results: Of the 60 subjects assessed, $70 \%$ had at least one diagnosis of dysfunction. Of these, $52.4 \%$ had mild TMD, 33.3\% had moderate and $14.2 \%$ had severe. Of individuals diagnosed with TMD, 30 are female and 12 male. Conclusion: Although no significance found in the statistical tests, we can demonstrate the relevance percentage in degree of severity in various regions of the spine, highlighting the cervical region, where all patients with pain at this location had some degree of TMD, and low back pain as the symptom most found in research, whether present or not some degree of TMD.
\end{abstract}

Keywords: "Temporomandibular Joint", "Tmj Syndrome", "Back Pain" and "Spine".

\section{RESUMO}

Introdução: A Disfunção Temporomandibular (DTM) é um composto de sinais e sintomas manifestados em consequência de desordens no sistema estomatognático. Desordens na Articulação Temporomandibular podem provocar problemas na coluna lombar e na cervical e vice-versa. Objetivo: identificar a prevalência de DTM em pessoas com dor na coluna vertebral. Método: Trata-se de um estudo transversal quantitativo analítico. Fizeram parte do estudo 60 voluntários, de ambos os sexos, de quatro clínicas de fisioterapia ortopédica, com pacientes em tratamento de quadros dolorosos vertebrais na cidade de Goiânia - GO. Foi utilizado o Questionário Anamnésico de Fonseca (1994) para captação e interpretação dos dados, bem como verificação da disfunção temporomandibular para caracterizar a severidade dos sintomas de DTM. O software utilizado para os testes estatísticos foi o BioEstat 5.0. Resultados: Dos 60 sujeitos avaliados, 70\% apresentaram pelo menos um diagnóstico da disfunção. Destes, 52,4\% apresentaram DTM leve, 33,3\% apresentaram DTM moderada e 14,2\% apresentaram DTM severa. Dos indivíduos diagnosticados com DTM, 30 são do sexo feminino e 12 do sexo masculino. Conclusão: Embora não se tenha encontrado significâncias nos testes estatísticos, pode-se demonstrar percentualmente as relevâncias no grau de severidade em várias regiões da coluna, colocando em destaque a região cervical, onde todos os pacientes que aceitaram participar da pesquisa com dor nesse local apresentaram algum grau de DTM, e a lombalgia como o sintoma mais encontrado na pesquisa, independente de apresentar ou não algum grau de DTM.

Palavras-Chave: "Articulação Temporomandibular", "Síndrome da ATM", "Coluna Vertebral” e "Dor nas Costas".

Corresponding author: Dr. Thiago Vilela Lemos. Rua T-53, Quadra 88, Lote 10/11, n. 692, Apt. 801, Residencial Twenty Three, Setor Bueno. Goiânia/GO - Zip Code: 74 215 150. Phone: (62) 8111 - 5551 - Email: tvlemos@gmail.com

${ }^{1}$ Universidade Salgado de Oliveira (Universo), Brasília (DF), Brazil; 2 Universidade Estadual de Goiás (UEG), Anápolis (GO), Brazil.

Financial support: There was no financial support for research, the same happened to the funding itself.

Submission date 8 July 2015; Acceptance date 5 October 2015; Online publication date 15 October 2015 


\section{INTRODUCTION}

One of the biggest annoyances of the population are back pain, which are usually linked to poor posture, stress or vertebral pathologies. ${ }^{(1)}$ Grazia et al $^{(2)}$ reported that pain in the spine resulting from poor posture in static or dynamic and that problems may arise by inactivity and poor posture. In several West countries, pains in the spine are considered a public health problem. ${ }^{(3)}$

These vertebral pains are a serious problem in modern society, where multidisciplinary teams seek to develop standards for a proper assessment of the spine. ${ }^{(4)}$

Regarding the vertebral painful conditions it is estimated that the current prevalence is around $30 \%$, and from $70 \%$ to $80 \%$ in a lifetime. ${ }^{(3)}$ One of the most common symptoms in adults in the west part of the world is low back pain. It is also noted that often patients with this diagnosis report widespread pain from soft tissue and other sites ${ }^{(5)}$ being also associated with other pains. ${ }^{(6)}$ In the general population, the absence of low back pain during the life is something extraordinary. ${ }^{(7)}$ These back pain can originate from neighboring regions or even from a distance, with multifactorial causes. ${ }^{(8)}$

As well as pains in the spine, temporomandibular disorder (TMD) is multifactorial, and often patients have postural problems, ${ }^{(2)}$ and this review should be multidisciplinary. ${ }^{(9)}$ The temporomandibular disorders (TMD) is a compound of signs and symptoms as a result of disorders in stomatognatic system. ${ }^{(10)}$ In general, TMD affects various tissue structures, causing a range of symptoms radiating distinct structures. ${ }^{(11)}$

Although it can occur at any age, it is more common among individuals 20-45 years. This dysfunction is four times more prevalent in women than in men. ${ }^{(12)}$ In others epidemiological studies have reported that over half of the population have at least one or more signals of TMD. ${ }^{(12,13)}$

TMD is characterized by one or more of the following factors: pain and tenderness of the masticatory muscles, limitation of motion of the jaw and sounds in the temporomandibular joint (TMJ) during jaw function. ${ }^{(14)}$

For Yi; Guedes; Vieira ${ }^{(15)}$ functional disorders of the masticatory muscles caused by muscle hyperactivity account for $80 \%$ of the etiology of TMD. Whereas this is a condition specified by signs and symptoms, these should be organized in a standardized, clear and workable way to evaluate and correct classification of TMD, as well as its etiological possibilities. ${ }^{(16)}$ Knowledge of these etiologies allows for proper diagnosis and treatment planning of TMD. ${ }^{(17)}$

The inspection of the cervical spine is recommended as part of thorough physical examination to detect DTM. Disorders of the cervical spine are chronic conditions affecting the cervical region and interconnected structures with or without radiation of pain to the head. ${ }^{(14)}$

Thus the dysfunctions can be correlated with spinal dysfunctions in TMJ since, have a kinesiology and anatomical relationship. ${ }^{(1)}$
In accordance with the presented relationship, another author attributes the relationship to mostly close ties caused by the fascia, where conditions in the cervical and lumbar spine can cause problems in TMJ and vice versa. It also highlights the importance of identifying the source of problems, in case if occur ascendende or descending order, as this procedure is essential to patient care. ${ }^{(18)}$

It is described in the literature that there is a relationship between the TMD and diseases in the cervical spine, (19) however, this study aims to correlate the whole spine with the TMD, and from the moment you have an established relationship between TMD and pains in the spine, scientifically proven, approach to the patient can become more complete.

Understanding the possible relationship TMD/spine pain, can guide the best treatment for the patient with at least one of these conditions, and starting this application, the aim of this study was to identify the prevalence of TMD in people with pain in the spine, and more specifically, check the site of greatest intensity of pain, assessing the degree of severity of the symptoms of TMD.

\section{METHOD}

It is an analytical quantitative cross-sectional study. Study participants were 60 volunteers of both sexes, who are in the age group above 18 years of age.

The inclusion criteria were: to present vertebral painful conditions, both genders, be older than 18 , live in the city of Goiânia and have TMD. Were excluded from the study: pregnant women, illiterate, have cognitive problems that limited their participation in research, neurological problems, fails to appear at all stages of the study, patients in the last six months have suffered injury and/or surgery on the face.

This study was conducted in four orthopedic physical therapy clinics, with patients being treated for vertebral painful conditions in the city of Goiania - GO. The instruments used for research were: Fonseca Anamnesic Questionnaire ${ }^{(20)}$ to characterize the severity of symptoms of TMD and evaluation form for obtaining and storing patient data.

Records were selected from patients who were on treatment of vertebral painful conditions. The interview lasted about 5 minutes, this period was the IC, and after the positive response, it was clarified and applied Fonseca Anamnesic Questionnaire. ${ }^{(20)}$

Subsequently, a survey was made of the data obtained to detect the region of the spine with the highest incidence of painful conditions; It evaluated the severity levels of the symptoms of TMD according to the classification imposed by Fonseca Questionnaire, where the individual without TMD will have to get $0-15$ points, mild TMD, 20-45 points, moderate TMD, 5065 points, and, lastly, severe TMD, 70 to 100 points.

Tabulation and statistical analysis were performed in the Excel spreadsheet program. After tabulating the data, it made use of descriptive statistics to inferential statistics and Excel 
program using the BioEstat 5.0 software. The $p$ value was considered statistically significant when $<0.05$.

Data analysis was done by concatenating questionnaire data, the evaluation form and storage of patient data, and the clinical diagnosis of the patient, in order to determine which regions of the spine and pain intensity more present relationship with the DTM.

All development work obeyed the rules of the Comissão Nacional de Ética em Pesquisa (CONEP), ensuring the confidentiality of the identity of the participants and the data collected during the search. This study was submitted to and approved by the Research Ethics Committee by Plataforma Brasil, Presentation of Certificado de Apresentação para Apreciação Ética (CAAE): 11954612.8.00005289. It was also properly applied the Informed Consent and Informed to give the individual a better understanding of the project and to inform the conditions of participation.

\section{RESULTS}

Were evaluated 60 volunteers in 4 clinics in Goiania who were in treatment for back pain. By Fonseca Questionnaire and the Data Storage Sheet, it was noted the prevalence of $T M D$, the severity, pathology and region of the spine with algia.

Of the 60 patients evaluated, 30\% $(n=18)$ did not show signs and / or clinical symptoms of TMD, as in $70 \%(n=42)$ was observed at least a diagnosis of the disorder. Of the total evaluated, 38 are women and 22 are men, and the individuals diagnosed with TMD, 30 are females and 12 males, showing that women had higher presentation of TMD symptoms, shown in Table 1.

Observing the degree of severity of TMD, as we can see in Figure 1, the majority had mild TMD, followed by moderate and severe TMD consecutively in both genders.

Table 1. Presence of TMD, according to gender.

\begin{tabular}{ccc}
\hline & Yes & No \\
\hline Male & $54.50 \%$ & $45.50 \%$ \\
Female & $78.90 \%$ & $21.10 \%$ \\
\hline
\end{tabular}

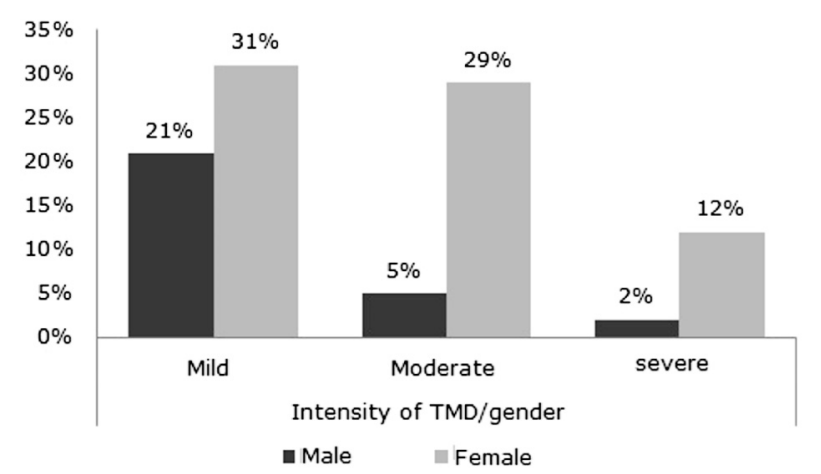

Figure 1. TMD degree of intensity, according to gender, of patients with TMD.
The prevalence of pain in the spine of patients with TMD, occurred as follows: lumbar spine $62 \%(n=26)$, followed by cervical spine $28.5 \%(n=12)$, cervical and lumbar spine $7.1 \%$ $(n=3)$ and thoracic spine $2.4 \%(n=1)$. Observed in Table 2.

Referring to the level of TMD according to pain in the region, we can still be seen in Table 2 , that 16 individuals with low back pain had mild degree of severity, 7 moderate and 3 severe. Since patients with pain in the neck, 4 of them had mild, 6 moderate and 2 severe. Among the patients with pain in the cervical and lumbar spine, 1 had mild, 1 moderate and 1 with severe degree. Finally, patients with cervical pain had a mild degree of severity.

Importantly, when considering all patients $(n=60)$ perceive themselves at all with pain in the cervical spine some degree of severity of TMD, which was not observed in those with pain in other regions of the spine.

According to Figure 2, of the subjects, $17 \%$ of men reported low back pain with mild degree of severity, whereas with the same $5 \%$ level reported neck pain. Of women diagnosed with mild degree of severity, $21 \%$ complained of back pain, cervical pain $5 \%$, and $2 \%$ for thoracic region, and cervical and lumbar regions. Of the subjects of the male gender who have moderate degree of severity, $2 \%$ reported pain in the cervical

Table 2. TMD degree of intensity, according to the pain area.

\begin{tabular}{lcccc}
\hline \multirow{2}{*}{ Pain area } & \multicolumn{3}{c}{ DTM intensity } & \multirow{2}{*}{ Total } \\
\cline { 2 - 4 } & Mild & Moderate & Severe & \\
\hline Lumbar spine & $61.5 \%(n=16)$ & $27 \%(n=7)$ & $11.5 \%(n=3)$ & $n=26$ \\
Cervical spine & $33.3 \%(n=4)$ & $50 \%(n=6)$ & $16.7 \%(n=2)$ & $n=12$ \\
Cervical and & $33.3 \%(n=1)$ & $33.3 \%(n=1)$ & $33.3 \%(n=1)$ & $n=3$ \\
Lumbar spine & $100 \%(n=1)$ & $0 \%(n=0)$ & $0 \%(n=0)$ & $n=1$ \\
Thoracic spine & 22 & 14 & 6 & $n=42$ \\
Total & & & & \\
\hline
\end{tabular}

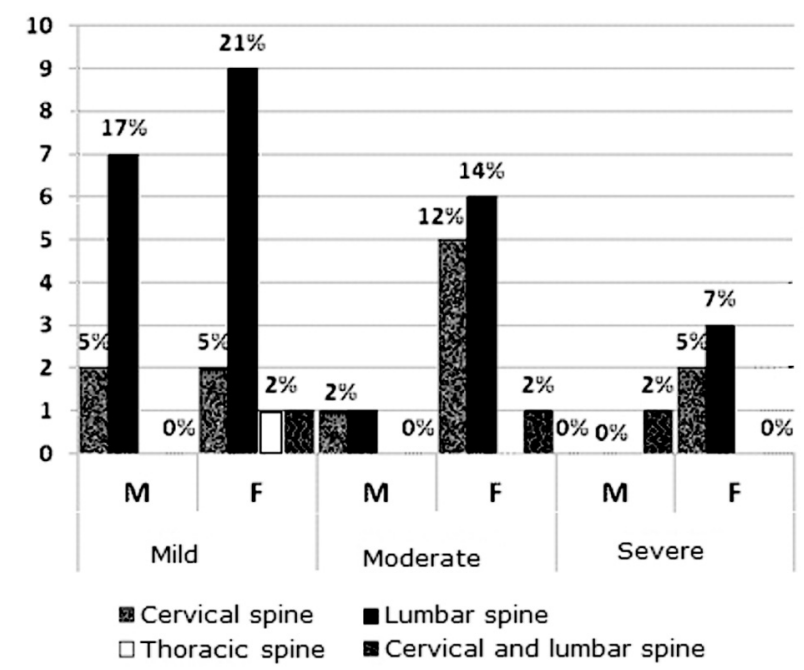

Figure 2. DTM intensity grade, sex and pain in the area. Legend: $M=$ male, $\mathrm{F}=$ female. Acronyms: $\mathrm{M}$ - Male and $\mathrm{F}$ - Female. 
and lumbar region. Already female, $14 \%$ reported pain in the lumbar region, $12 \%$ cervical and $2 \%$ Cervical and Lumbar.

Of Women diagnosed with severe TMD, 7\% suffered from pain in the lumbar and cervical spine $5 \%$, while $2 \%$ of the male sample with TMD presented severe and complained of pain in the cervical and lumbar regions.

\section{DISCUSSION}

From the analysis of the results there was a high prevalence of TMD in patients with pain in the spine, being this prevalence of $70 \%$ compared to 60 subjects evaluated.

These figures coincide with a case-control study, which evaluated a total of 616 patients with varying severity of back pain or no pain in the spine. The evaluated completed a questionnaire focusing on the symptoms in the jaw region, head and spine. They concluded that there is a reciprocal relationship between back pain and TMD. The results indicate that these two conditions may share common risk factors or that can influence each other. ${ }^{(6)}$

In a prospective study ${ }^{(21)}$ were selected 98 volunteers with TMD of both genders and submitted to an Fonseca Anamnesic questionnaire. The data showed that $68.36 \%$ had mild dysfunction, $23.47 \%$ moderate and severe $8.16 \%$, a result that is in line with the data obtained in this study.

A study seeking to verify the reliability of the Fonseca anamnesis questionnaire, applied it in a population comprised of 599 female volunteers and 631 males with ages ranging $15-64$ years, mean $38.3 \pm 13.76$ years. Of the subjects, 278 (22.60\%) showed no DTM; 770 (62.60\%) had mild TMD; $126(10.24 \%)$ had moderate TMD, and 56 (4.56\%) severe TMD. ${ }^{(22)}$

For greater reliability of the questionnaire proposed by Fonseca, suggests an adaptation to include only questions 1 , $2,3,6$ and 7 , thereby contributing to increased reliability of the instrument. ${ }^{(22)}$

Relating the region of the spine with greater pain complaint and the degree of severity was noted that the 26 showed that lumbar pain, 16 were diagnosed with mild degree of severity 7 with moderate degree of severity and 3 with severe.

Of the subjects who reported neck pain, with 4 degree of mild severity, with a little more, 6 with moderate degree of severity and only two with severe degree. In the thoracic region we found only one subject, where it was diagnosed with mild degree of severity. Finally, three individuals complained of pain in the cervical and lumbar regions with a different degree of severity in each person.

The chi-square test shows that the intensity of the TMD is independent of pain in the region, with $p=0.5918$.

All subjects who reported neck pain have some degree of TMJ involvement, confirming recent studies, such as a survey in which they were evaluated 71 women divided into two groups, with and without TMD, the group of people with TMD in $88.24 \%$ reported neck pain. ${ }^{(23)}$
Another survey conducted in Poland, which conducted a randomized controlled trial with follow up 3 months and sought to establish a relationship between TMD pain and mobility of the cervical spine. They found that after treatment with an occlusal splint in the experimental group was obtained improves mobility and cervical pain with statistical significance, and confirmed when compared to the control group. Therefore their results confirmed a correlation between the disease and the positive effects of treatment within the motor aspect of the stomatognathic system in relieving pain in the cervical spine. ${ }^{(19)}$

Of the 60 patients evaluated, 38 are women and 22 are men, and the individuals diagnosed with TMD, 30 are female and 12 male. Several studies show that the signs and symptoms of TMD are found more frequently in women. ${ }^{(12,24,25)}$

The chi-square test shows that the presence of the TMD is independent of gender, with $p=0.0900$. This means we can not say that a group has a higher occurrence of TMD than the other.

In contrast, a survey of descriptive type with a cross sample, consisting of 221 patients in which 83 patients with the missing TMD index, 37 patients (16.74\%) were females and $46(20.82 \%)$, male. ${ }^{(13)}$ In this same study of Silveira ${ }^{(13)}$ of the 48 subjects with any degree of severity, 35 were females (72.9\%) and 13 to males (27.1\%).

\section{CONCLUSION}

There has been a high prevalence of TMD in people with pain in the spine. The lumbar region showed the biggest complaint of pain, and most of those surveyed were diagnosed with mild degree of severity.

Although there was found significance in statistical testing, we can show in percentage terms the relevance of the degree of severity in various regions of the column, featured in putting the cervical region, where all patients who agreed to participate in pain at that location had some degree of TMD, and low back pain as the symptom most commonly found in the search, regardless of whether or not it some degree of TMD.

Through these results, it is believed a positive contribution to the interest of new research which is focused on the cervical region, because everyone who had pain at this location obtained some degree of TMD.

\section{ACKNOWLEDGMENTS}

To all those who directly or indirectly contributed to carrying out the work.

A special way to our advisors, Prof. Esp. Diogo Suriani Ribeiro and Prof. Dr. Thiago Vilela Lemos for the support, guidance, confidence and commitment devoted to the elaboration of this work.

\section{AUTHOR'S CONTRIBUTIONS}

DSR: Students' orientation, review and manuscript preparation and submission to the ethics committee; BGS: Literature review, project construction and data collection; NSO: Literature review, project construction 
and data collection; AOA: Literature review, project construction and data collection; MGRS: Literature review and drafting of the article; LGCS: Literature review and drafting of the article; TVL: students of guidance and reviewing the manuscript.

\section{COMPETING INTERESTS}

We declare not have any conflicts of interest and / or support resources.

\section{REFERENCES}

1. Tosato JdP, Gonzalez TdO, Sampaio LMM, Corrêa JCF, Gonzalez DAB. Prevalência de sinais e sintomas de disfunção temporomandibular em mulheres com cervicalgia e lombalgia. Arquivos médicos do $A B C$. 2007;32(2):20-2.

2. Grazia R, Bankoff A, Zamai C. Alterações posturais relacionadas com a disfunção da articulação temporomandibular e seu tratamento. Mov Percepção. 2006;6(8):150-62.

3. Meziat Filho N, Silva G. Invalidez por dor nas costas entre segurados da Previdência Social do Brasil. Rev Saúde Públ. 2011;45(3):494-502.

4. Alexandre NMC, Moraes MAA. Modelo de avaliação físico-funcional da coluna vertebral. Rev Latino-Am Enfermagem. 2001;9(2):67-75.

5. Jöud A, Petersson I, Englund M. Low Back Pain: Epidemiology of Consultations. Arthritis Care Res. 2012;64(7):1084-8.

6. Wiesinger B, Malker H, Englund E, Wanman A. Does a dose-response relation exist between spinal pain and temporomandibular disorders? BMC Musculoskel Disord. 2009;10(1):28.

7. Lemeunier N, Kongsted A, Axen I. Prevalence of pain-free weeks in chiropractic subjects with low back pain - a longitudinal study using data gathered with text messages. Chiropr Man Therap. 2011;19(1):28.

8. Brazil A, Ximenes A, Radu A, Fernades A, Appel C, Maçaneiro C, et al. Diagnóstico e tratamento das lombalgias e lombociatalgias. Rev Bras Reumatol. 2004;44:419-25.

9. Manfredi APS, Silva AAD, Vendite LL. Avaliação da sensibilidade do questionário de triagem para dor orofacial e desordens temporomandibulares recomendado pela Academia Americana de Dor Orofacial. Rev Bras Otorrinolaringol. 2001;67(6):763-8.

10. Biasotto-Gonzalez D. Abordagem interdisciplinar das disfunções temporomandibulares. São Paulo: Manole; 2005. 246 p.

11. Correa AL, Pereira JS, Silva MAGd. Avaliação dos desvios posturais em escolares: estudo preliminar. Fisioter Bras. 2005;6(3):175-8.

12. Silva GR, Martins PR, Gomes KA, Di Mambro TR, de Souza Abreu N. O efeito de técnicas de terapias manuais nas disfunções craniomandibular. Rev Bras Cien Med Saúde. 2011;1(1):17-22.
13. Silveira AM, Feltrin PP, Zanetti RV, Mautoni MC. Prevalência de portadores de DTM em pacientes avaliados no setor de otorrinolaringologia. Rev Bras Otorrinolaringol. 2007;73:528-32.

14. Wijer A, Steenks M, Bosman F, Helders P, Faber J. Symptoms of the stomatognathic system in temporomandibular and cervical spine disorders. J Oral Rehabil. 1996;23(11):733-41.

15. Yi LC, Guedes ZCF, Vieira MM. Relaçao da postura corporal com a disfunçao da articulaçao temporomandibular: hiperatividade dos musculos da mastigaçao. Fisioter Bras. 2003;4(5):341-7.

16. Chaves TC, Oliveira ASd, Grossi DB. Principais instrumentos para avaliação da disfunção temporomandibular, parte I: índices e questionários; uma contribuição para a prática clínica e de pesquisa. Fisioter Pesqui. 2008;15(1):92-100.

17. Machado LPS, Nery MBM, Nery CG, Leles CR. Profiling the clinical presentation of diagnostic characteristics of a sample of symptomatic TMD patients. BMC oral health. 2012;12:26. Disponível em: http://www. ncbi.nlm.nih.gov/pmc/articles/PMC3500225/

18. Tedeschi-Marzola F. A estreita relação entre a coluna cervical e a articulação têmporomandibular - Aspectos fisioterapêuticos. Academia Tiradentes de Odontologia. 2005;5(3):346-61.

19. Walczyńska-Dragon K, Baron S, Nitecka-Buchta A, Tkacz E. Correlation between TMD and Cervical Spine Pain and Mobility: Is the Whole Body Balance TMJ Related? Biomed Res Int. 2014;2014:1-7. Disponível em: http://www.hindawi.com/journals/bmri/2014/582414/

20. Fonseca DMd, Bonfante G, Valle ALd, Freitas SFTd. Diagnóstico pela anamnese da disfunção craniomandibular. Rev Gaúcha Odontol. 1994;42(1):23-4, 7-8.

21. Biasotto-Gonzalez DA, Andrade DVd, Gonzalez TdO, Martins MD, Fernandes KPS, Corrêa JCF, et al. Correlação entre disfunção temporomandibular, postura e qualidade de vida. Rev Bras Crescimento Desenvolv Hum. 2008;18(1):79-86.

22. Campos JADB, Gonçalves DAG, Camparis CM, Speciali JG. Confiabilidade de um formulário para diagnóstico da severidade da disfunção temporomandibular. Rev Bras Fisioter. 2009;13(1):38-43.

23. Weber P, Corrêa ECR, Ferreira F, Soares JC, Bolzan G, Silva A. Frequência de sinais e sintomas de disfunção cervical em indivíduos com disfunção temporomandibular. J Soc Bras Fonoaudiol. 2012;24(2):134-9. Disponível em: http://www.scielo.br/pdf/jsbf/v24n2/pt_08.pdf.

24. Oliveira Saes M, Nogueira DB, Silveira MS, Siqueira FCV. Perfil epidemiológico dos pacientes com disfunção temporomandibular: Uma abordagem fisioterápica. Rev Inspirar Mov Saude. 2013;5(1):1-5. Disponível em: http://inspirar.com.br/revista/?p=2588

25. Siqueira SRDTd, Almansa NK, Teixeira MJ, Siqueira JTTd. Levantamento epidemiológico de dor da clínica odontológica do SESC Santo André, Brasil. Rev Dor. 2008;9(2):1225-33. 